\title{
Korisnici u COBISS okruženju - iskustva Narodne biblioteke Užice
}

\author{
Users in the COBISS environment - experiences at the \\ Public Library of Užice
}

\section{Gordana Bacotić ${ }^{1}$, Biljana Ristović ${ }^{2}$}

SAŽETAK: Narodna biblioteka Užice anketirala je 2019. godine svoje korisnike s ciljem da proveri koliko oni poznaju proces pretraživanja kataloga u aplikaciji COBISS/OPAC (sada COBISS+). Istraživanje se sastojalo iz sledećih segmenata: profil korisnika, najčešće korišćene pristupne tačke, korišćenje ekranskih saveta i olakšica pri pretraživanju i korisnička procena dobijenih rezultata. Uprkos tome što se obuka korisnika za pretraživanje u COBISS/OPAC kontinuirano sprovodila, rezultati istraživanja su pokazali da mogućnosti, koje je nudio COBISS/OPAC, nisu bile dovoljno iskorišćene. Korišćenje bibliotečkih kataloga zahteva veće znanje i angažovanje nego pretraživanje na internetu. Katalog se koristi za pronalaženje već poznatih jedinica građe u fondu Biblioteke, a ne za složena tematska pretraživanja koja su prepuštena bibliotekarima.

KLJUČNE REČI: COBISS/OPAC, katalog, korisnici, pretraživanje, anketa, Narodna biblioteka Užice

ABSTRACT: In 2019, the Public Library of Užice conducted a survey to assess the level of user knowledge of the search process in COBISS/OPAC (now COBISS+). The survey consisted of the following segments: user profile, most commonly used access points, use of screen tips and ease of searching, and user evaluation of the search results obtained. Although user training for searching COBISS/OPAC was carried out continuously, the survey results have shown that the options in COBISS/OPAC were not sufficiently used. Using library catalogues requires more knowledge and engagement than searching the Internet. The catalogue is used for finding already known items in the library's holdings, and not for topical searches, which are left to librarians.

KEYWORDS: COBISS/OPAC, catalogue, users, search, survey, Public Library of Užice

\section{Uvod}

Razvoj informacionih tehnologija doneo je značajne promene u bibliotečkom poslovanju, a posebno u izradi kataloga i njihovom korišćenju. Između ostalog, pojava uzajamne katalogizacije omogućila je veliku uštedu u vremenu pri obradi bibliotečke građe; lisni katalozi su zamenjeni elektronskim kojima se pristupa i preko interneta, što bi trebalo da predstavlja veliku olakšicu, ne samo za bibliotekare, već i za korisnike bibliotečkih usluga. U lisnim katalozima, zapisima se pristupalo samo preko autora, naslova i predmeta (elementi za način ulaganja listića u katalog), dok u onlajn katalogu različiti elementi opisa mogu biti pristupne tačke (Svenonius, 2007, str. 44). Uprkos tome što bibliotečki katalozi pružaju različite mogućnosti pretraživanja, njihovo je korišćenje daleko manje od očekivanog, jer je njihova upotreba za korisnike složenija od upotrebe internet pretraživača koji su postali neizbežni u svakodnevnom profesionalnom i privatnom životu. Pored očekivanja da će se povećavati broj

\footnotetext{
${ }^{1}$ Kontakt autor: Gordana Bacotić, viši diplomirani bibliotekar, Narodna biblioteka Užice, Užice, Srbija gbacotic@gmail.com.

2 Biljana Ristović, viši diplomirani bibliotekar, Narodna biblioteka Užice, Užice, Srbija, biljana.ristovic76@gmail.com.
} 
korisnika kataloga, naročito zbog toga što su se katalozi tokom godina razvijali, menjali i donekle prilagođavali korisničkom načinu razmišljanja, prema iskustvu zaposlenih u Narodnoj biblioteci Užice, korisnici se i dalje u velikoj meri oslanjaju na pomoć bibliotekara.

U Srbiji je 2019. godine više od 220 biblioteka bilo uključeno u COBISS sistem koji bibliotekarima i korisnicima omogućava onlajn pristup, ne samo lokalnim bazama podataka, već i uzajamnoj bibliografsko-kataloškoj bazi COBIB i specijalizovanim bazama podataka.

Narodna biblioteka Užice deo je sistema uzajamne katalogizacije COBISS od 2004. godine i prva je javna biblioteka koja se priključila ovom sistemu (Ršumović, 2006, str. 206), čime je njen fond postao vidljiv i pretraživ preko interneta. Sve do polovine 2019. godine korišćena je aplikacija COBISS/OPAC koja je kasnije zamenjena aplikacijom COBISS+.

Pretraživanje onlajn kataloga COBISS/OPAC bilo je prilagođeno različitim zahtevima i stepenu znanja korisnika (Šokica, 2005, str. 34). Postojala su tri načina pretraživanja COBISS/OPAC: osnovno, izborno i komandno, što je uz određene modifikacije ostalo i u COBISS+. Osnovno pretraživanje je najjednostavnije i prilagođeno je korisnicima koji pretražuju rečima ili sintagmama koje se nabrajaju. Za ovo pretraživanje nije potrebno veće predznanje, jer podseća na okvir za pretragu (search box) internet pretraživača. Izborno pretraživanje je nešto složenije, podrazumeva korišćenje Bulovih operatora i pruža mogućnost kombinovanja niza parametara. Podrazumevani operator je »/« (And), a za primenu ostalih operatora potrebno je veće predznanje i angažovanje korisnika.

Komandno pretraživanje je najsloženija vrsta pretraživanja koja podrazumeva upotrebu indeksa za pretraživanje (prefiksi i sufiksi) i kontekstualnih operatora With i Near (u COBISS+ aplikaciji nema operatora With). "Mogućnosti pretraživanja u komandnom načinu rada su velike i njih koriste uglavnom bibliotekari. “(Šokica, 2005, str. 40). Za ovu vrstu pretraživanja potrebno je obučiti korisnike, a ponekad se traži i poznavanje bibliografsko-kataloške obrade.

Kada je reč o pretraživanju, prelazak na COBISS+ verziju doneo je više promena. Prema prvim komentarima korisnika u Narodnoj biblioteci Užice, novi interfejs je donekle teži za snalaženje, jer su neke opcije na početnom ekranu manje upadljive (na primer, link za izborno i komandno pretraživanje). Katalog, koji je prilagođen korisniku, trebalo bi da omogući jasna i uvek dostupna uputstva tokom procesa pretraživanja. Ako čitanje uputstava podrazumeva višestruko otvaranje i zatvaranje prozora, to ometa i usporava pretraživanje, posebno ako je uputstvo detaljno. U verziji COBISS/OPAC saveti za pretraživanje nalazili su se s desne strane prozora za pretraživanje, dok su u COBISS+ manje uočljivi, a takođe nije eksplicitno naglašeno da link više informacija, koji postoji na pristupnoj strani, vodi ka savetima za pretraživanje. Čitanje uputstva podrazumeva izlazak iz prozora za pretraživanje, što dodatno otežava pretragu.

Između ostalog, prednosti COBISS+ verzije su mogućnost dodavanja novih polja u prozoru za pretragu u izbornom pretraživanju, fasetna navigacija kojom se filtriraju dobijeni rezultati pretraživanja, a takođe brojne mogućnosti personalizovane pretrage povezane s profilom Moj COBISS.

Neki suštinski problemi s kojima se korisnici susreću prilikom pretrage kataloga ostali su, međutim, nepromenjeni, a time se ovaj rad i bavi. 


\section{COBISS i obuka korisnika u Narodnoj biblioteci Užice}

Prelazak s lisnih na elektronske kataloge počeo je u Narodnoj biblioteci Užice sredinom devedesetih godina 20. veka. U početku je korišćen Uneskov softver za bibliotečko poslovanje (DOS verzija) koji je bio previše zahtevan za korisnike. U praksi, korisnici nikada nisu samostalno pretraživali katalog korišćenjem ovog sistema. Prema iskustvu zaposlenih, ni prelazak na znatno jednostavniju COBISS/OPAC aplikaciju nije doprineo značajnijem osamostaljivanju korisnika pri pretraživanju.

Odmah posle obuke bibliotekara za rad u COBISS/OPAC okruženju, započela je obuka zainteresovanih korisnika za samostalnu pretragu COBISS/OPAC, u cilju njihovog osposobljavanja za samostalno pronalaženje i pravilno korišćenje izvora informacija. Edukacija korisnika je permanentan proces koji se odvija na dva načina:

- individualno (u prostorijama Biblioteke);

- grupno (za učenike osnovnih i srednjih škola) u školskim informatičkim kabinetima.

Individualna obuka za pretraživanje u COBISS/OPAC odvijala se, uz redovan posao, u svim odeljenjima i bila je uslovljena vremenom koje su na raspolaganju imali korisnik i bibliotekar. Uglavnom se svodila na nekoliko osnovnih koraka: upoznavanje s lokalnom i uzajamnom bibliografsko-kataloškom bazom i razlikama između njih, s prozorom i opcijama za pretraživanje, s podacima o smeštaju i dostupnosti građe. Korisnicima, koji su tražili stručnu literaturu, objašnjena je razlika između ključne reči i predmetne odrednice. Takođe se skretala pažnja na skraćivanje termina zvezdicom $\left({ }^{*}\right)$, na upotrebu Bulovih operatora, na vezu s bazama punog teksta. Korisnicima smo najčešće pokazivali izborno pretraživanje jer je, za razliku od osnovnog, bilo više detaljno i pregledno, a manje komplikovano od komandnog. Zainteresovani su imali mogućnost da dobiju i detaljna uputstva od bibliotekara, a svima smo ukazivali na činjenicu da postoje saveti za pretraživanje. Korisnici su najčešće pokazivali interesovanje za učenje pretraživanja, ali i relativno kratkoročno strpljenje za detaljnija objašnjenja.

Grupna obuka bila je namenjena prvenstveno završnim razredima osnovnih i srednjih škola, a organizovana je i za nastavno osoblje i školske bibliotekare. Sprovedena je preko projekta Pronađi i koristi informaciju koji je podržalo Ministarstvo kulture i informisanja Republike Srbije 2014. godine. Ova obuka nastavljena je i po završetku projekta i ujedno postala redovna aktivnost u Narodnoj biblioteci Užice. Do sada je njome obuhvaćeno preko 2000 učenika užičkih osnovnih i srednjih škola (Davidovski i Marinčić, 2019, str. 139). U okviru jednog od redovnih poslova Matične službe Narodne biblioteke Užice, sprovođena je edukacija učenika osnovnih i srednjih škola na teritoriji Zlatiborskog okruga za pretraživanje COBISS/OPAC, pod nazivom Pronađi pravu informaciju.

Obuka za pretraživanje u COBISS/OPAC bila je segment i u okviru drugih projekata: Ministarstvo kulture i informisanja podržalo je 2014. godine projekat Biblioteka - mesto susreta svih za učenike osnovnih škola u seoskim ograncima (Ribaševina, Karan i Lunovo Selo); na Dečjem odeljenju realizovan je projekat Biblioteka - mesto za učenje (Ministarstvo kulture i informisanja Republike Srbije 2018. godine); Grad Užice podržao je 2012. godine projekat Profil, anfas, poluprofil namenjen učenicima osnovne škole na području Knjižnog ogranka Sevojno. 
Grupna obuka je izvođena u kabinetima za informatiku tokom jednog školskog časa po unapred utvrđenom programu. Kada škola nije bila povezana sa internetom, što se retko događalo, učenicima je COBISS/OPAC predstavljen preko pripremljene prezentacije. Grupna obuka je bila strukturisana i detaljna, s predviđenim vremenom za vežbu, međutim, motivisanost učenika često je bila na nižem nivou u odnosu na korisnike koji su pokazivali interesovanje za individualnu obuku.

U okviru projekta Mladi u biblioteci koji je finansirao Grad Užice, Narodna biblioteka Užice je pokrenula i YouTube kanal, kao vid promovisanja svojih usluga, gde je jedan od video zapisa posvećen pretraživanju COBISS/OPAC (https://www.youtube.com/watch?v=AwqyGq6oh8c).

Svi oblici edukacije pokrenuti su zato što je iskustvo u radu pokazalo da je mali procenat korisnika pretraživao COBISS/OPAC i što su korisnici bili relativno nesamostalni pri pretraživanju. Osim toga, urađena je i empirijska studija u cilju sticanja što preciznijeg uvida u iskustva korisnika pri pretraživanju baze podataka.

\section{Koncept i metodologija}

Krajem 2018. i u prvoj polovini 2019. godine, u Narodnoj biblioteci Užice sprovedeno je istraživanje među korisnicima u cilju utvrđivanja njihovog poznavanja procesa pretrage COBISS/OPAC i zadovoljstva rezultatima pretrage. Konkretan cilj istraživanja bilo je ispitivanje snalaženja prosečnog korisnika usluga Narodne biblioteke Užice u COBISS/OPAC okruženju.

U istraživanju su postavljene sledeće hipoteze:

1. COBISS/OPAC se najčešće koristi za pretraživanje po parametrima poznatim korisniku (korisnici pretražuju da li biblioteka poseduje određeni naslov ili dela određenog autora);

2. korisnici ne koriste sve mogućnosti pretraživanja (Bulovi operatori, skraćivanje);

3. pretraživanje po temi suviše je složeno za korisnika;

4. korisnici nisu zadovoljni rezultatima pretrage COBISS/OPAC.

Korišćena je metoda ankete. Prva faza istraživanja podrazumevala je usmeno ispitivanje korisnika starijih od 15 godina na Pozajmnom odeljenju za odrasle, s ciljem da se ustanovi da li pretražuju COBISS/OPAC. One, koji su se pozitivno izjasnili, zamolili smo da popune anketu. Po sistemu slučajnog uzorka obuhvaćeno je 100 korisnika različitog pola, uzrasta, obrazovanja i interesovanja. Anketiranje je sprovedeno od decembra 2018. do septembra 2019. godine i trajalo je duže od predviđenog vremena, jer se mali broj korisnika izjasnio da pretražuje u COBISS-u.

Anketnom obrascu u elektronskom obliku (onlajn Google upitnik), korisnici su pristupali u prostorijama Biblioteke, preko računara koji je namenjen korisnicima. Anketa je sadržala 15 pitanja zatvorenog tipa i sastojala se iz sledećih segmenata: profil korisnika (pol, zanimanje), korišćenje saveta i olakšica pri pretraživanju (zvezdica, Bulovi operatori), najčešće korišćene pristupne tačke (poseban osvrt na ključnu reč i predmetnu odrednicu), korisnička procena procesa pretraživanja i zadovoljstvo dobijenim rezultatima.

Odgovor na svako pitanje bio je obavezan. Bibliotekar je prisustvovao anketiranju i davao dodatna objašnjenja onda kada je korisnik to tražio. Izvršena je osnovna kvantitativna 
statistička analiza odgovora. U deskriptivnoj analizi, kao statistička tehnika korišćeni su procenti.

\section{Rezultati istraživanja}

U istraživanju je učestvovalo 100 ispitanika, od kojih je 65\% bilo ženskog i 35\% muškog pola. Ovaj odnos približan je polnoj strukturi ukupnog broja korisnika Biblioteke (66\% prema 34\%). Anketirano je 37 zaposlenih, 28 studenata, 19 učenika, 11 nezaposlenih i 5 penzionera.

$\mathrm{Na}$ pitanje kako su naučili da koriste COBISS/OPAC, 45\% je odgovorilo da je naučilo samostalno, a 55\% uz pomoć bibliotekara. Najveći procenat ispitanika, koji su tvrdili da su samostalno naučili da pretražuju, spada u kategorije studenata i zaposlenih, koji su u najproduktivnijem periodu učenja i usavršavanja u struci.

Kada je reč o korišćenju saveta za pretraživanje, koji su se u COBISS/OPAC nalazili pored maske za pretraživanje, od ukupnog broja ispitanika, $37 \%$ nije primetilo savete za pretraživanje koji se nalaze na stranici na kojoj se pretražuje, a $41 \%$ ih nije koristilo, iako su znali da postoje, dok je samo $22 \%$ koristilo ovu vrstu pomoći.

$U$ vezi s načinom pretraživanja u COBISS/OPAC, ispitanici su se u većini izjasnili da koriste osnovno pretraživanje (slika 1). Ispostavilo se da $16 \%$ ispitanika ne zna kako se zove pretraživanje koje koriste, a kroz razgovor je utvrđeno i da se nazivi pretraživanja mešaju. Zaključak je da većina koristi izborno pretraživanje na koje i bibliotekari upućuju prilikom obuke, jer je najpreglednije i usklađeno je s mogućnostima korisnika. Ovaj rezultat, takođe, ukazuje na činjenicu da obaveštenja na interfejsu u verziji COBISS/OPAC nisu bila dovoljno uočljiva (npr. različita boja, ikone), kako bi na sebe skrenula pažnju.

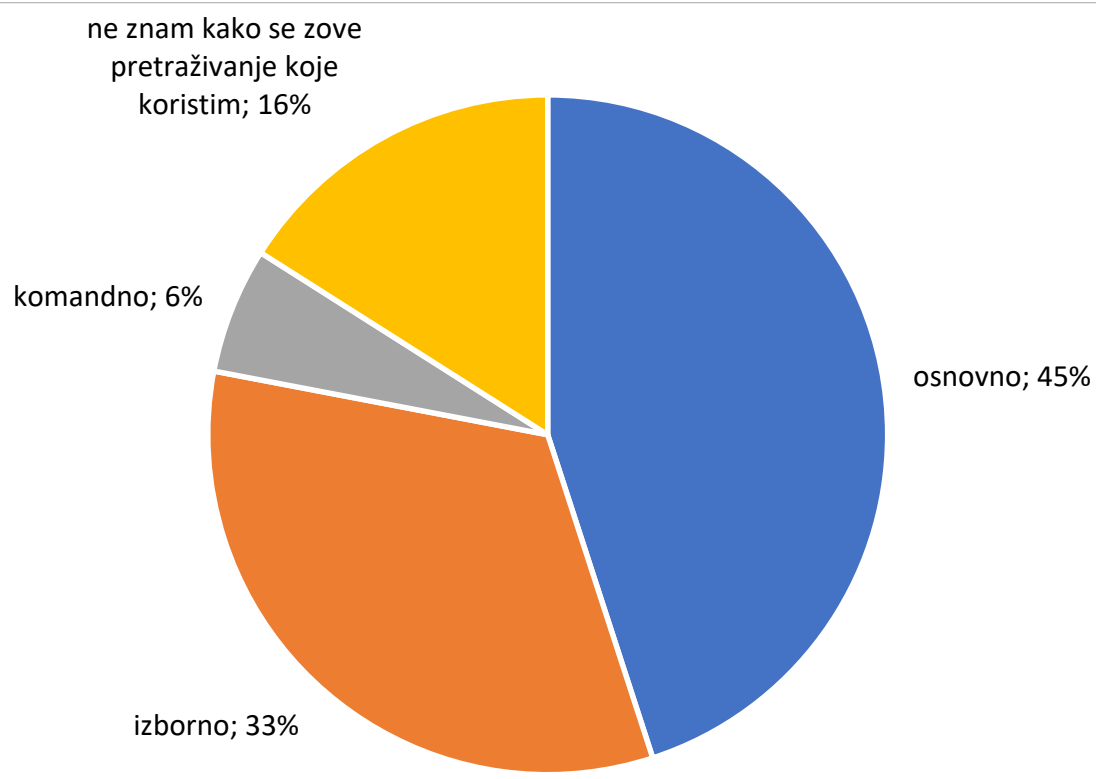

Slika 1: Načini pretraživanja u COBISS/OPAC ( $n=100$, u \%) 
Kada je reč o oblastima koje ispitanici pretražuju, najviše su zastupljene društvene nauke (51\%), zatim sledi beletristika (41\%), a najmanje se pretražuju teme iz prirodnih i primenjenih nauka (8\%). Fond javnih biblioteka čini $50 \%$ beletristike koja se prema godišnjim izveštajima najčešće i pozajmljuje. Ova oblast je najtraženija, ali prema rezultatima ankete nije i najčešće pretraživana, jer se pri izboru beletristike čitaoci najčešće oslanjaju na preporuku i pomoć bibliotekara. lako su liste najčitanijih knjiga i preporuke za čitanje dostupni u svim medijima, korisnici i dalje veruju preporuci bibliotekara, jer je ona prilagođena njihovom individualnom ukusu. Kroz višegodišnju interakciju, bibliotekar upoznaje afinitete korisnika, a istovremeno ima uvid u kvalitetne naslove koji nisu medijski propraćeni.

$\mathrm{Na}$ pitanje o najčešće korišćenim pristupnim tačkama prilikom izbornog pretraživanja u COBISS/OPAC, ispitanici su imali mogućnost višestrukog odgovora. Rezultati pokazuju da korisnici najčešće pretraživanjem proveravaju da li biblioteka poseduje određeni naslov ili dela određenog autora, dok je pretraživanje po temi ili oblasti (preko predmetne odrednice ili ključne reči) znatno ređe (slika 2).

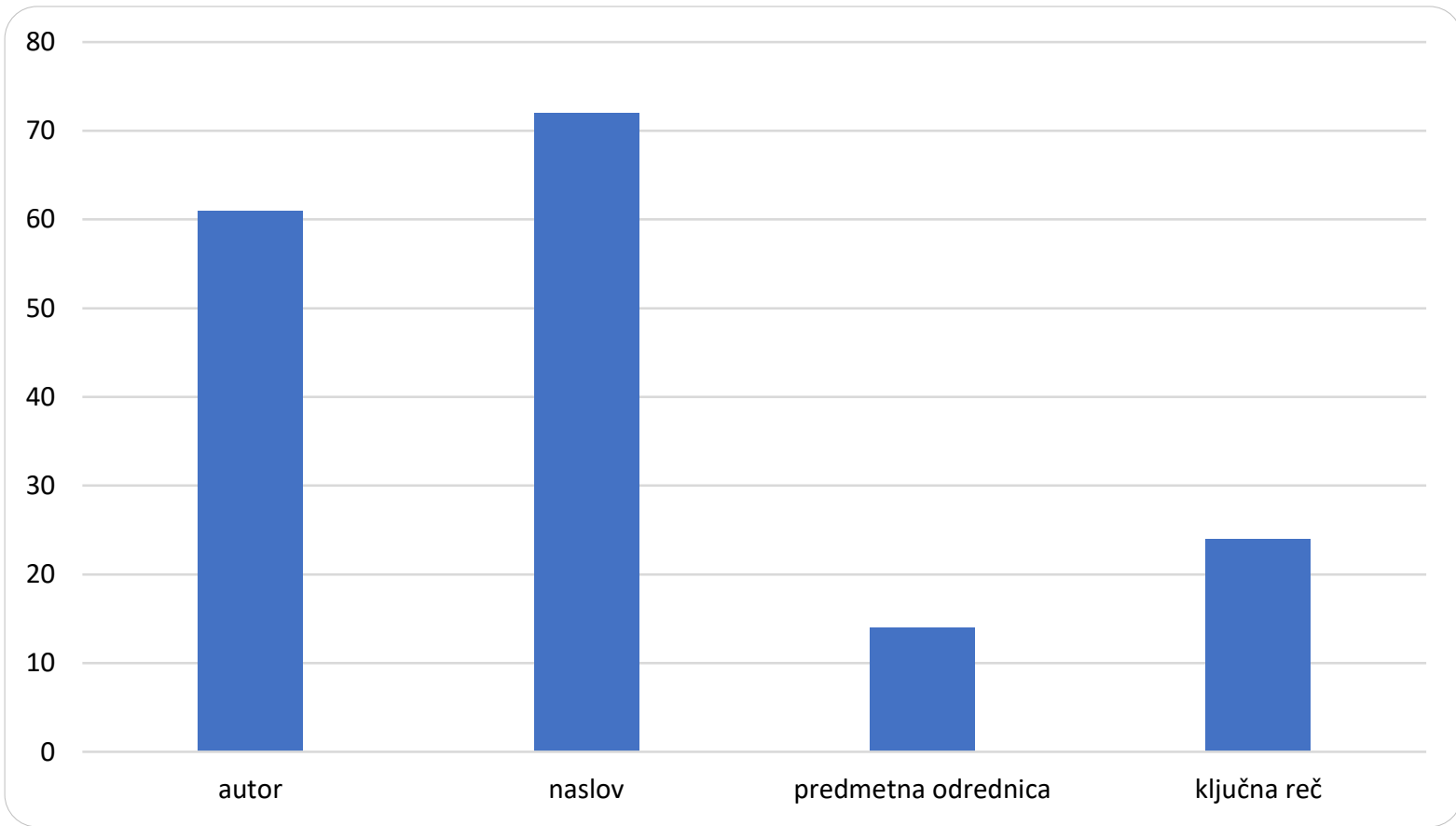

Slika 2: Najčešće korišćene pristupne tačke prilikom pretraživanja u COBISS/OPAC ( $n=100)$

Sledeća tri pitanja u anketi odnosila su se na upotrebu predmetne odrednice kao pristupne tačke pri pretraživanju. Na pitanje Koristite li opciju "predmetna odrednica" pri pretraživanju $29 \%$ ispitanika odgovorilo je da koristi, $47 \%$ da ne koristi, a $24 \%$ izabralo je opciju ne znam šta je predmetna odrednica, što znači da više od dve trećine anketiranih ne koristi predmetnu odrednicu kao pristupnu tačku. Među onima koji koriste predmetnu odrednicu, najbrojnija su lica iz kategorije studenata i zaposlenih.

Kada je reč o korišćenju ključne reči i predmetne odrednice pri pretraživanju, kada su autor i naslov dela nepoznati, $89 \%$ ispitanika se odlučuje za ključnu reč, a samo $11 \%$ za predmetnu odrednicu, što je dvostruko manje od procenta ispitanika koji su se u prethodnom pitanju 
izjasnili da koriste predmetnu odrednicu. Samo je jedan ispitanik iz kategorije studenata dao prednost predmetnoj odrednici u odnosu na ključnu reč, a ista osoba najčešće pretražuje oblast prirodnih i primenjenih nauka.

Treće, test pitanje, odnosilo se na procenu odnosa broja pogodaka dobijenih upotrebom ključne reči i broja pogodaka dobijenih upotrebom predmetne odrednice. Ispitanici su odgovarali na pitanje Više pogodaka može se dobiti pretragom preko ključne reči ili predmetne odrednice? Većina odgovora (80\%) prednost je dala ključnoj reči. Zanimljiv je podatak da od $11 \%$ ispitanika, koji su u prethodnom pitanju (Kada vam je nepoznat autor i naslov dela češće pretražujete ključne reči ili predmetne odrednice?) dali prednost predmetnoj odrednici u odnosu na ključnu reč, samo $2 \%$ smatra da se više pogodaka dobija preko ključne reči, što ukazuje na činjenicu da većina ne razume koncept predmetne odrednice.

Naredna dva pitanja odnosila su se na korišćenje olakšica pri pretraživanju. Tokom obuke, koju individualno ili grupno sprovode bibliotekari, najviše pažnje se poklanja skraćivanju pojma zvezdicom i upotrebi Bulovih operatora. Kada je reč o korišćenju zvezdice za skraćivanje pojma za pretraživanje, ispitanici su se izjasnili na sledeći način: $25 \%$ koristi zvezdicu, a $75 \%$ je ne koristi. Provera korišćenja Bulovih operatora formulisana je na način blizak korisnicima: Znate li da postoje opcije $i$, ili, ne pri pretraživanju i da li ih koristite? Zanimljivo je da čak 64\% ispitanika poznaje tu opciju, a da je relativno malo (23\%) koristi (slika 3).

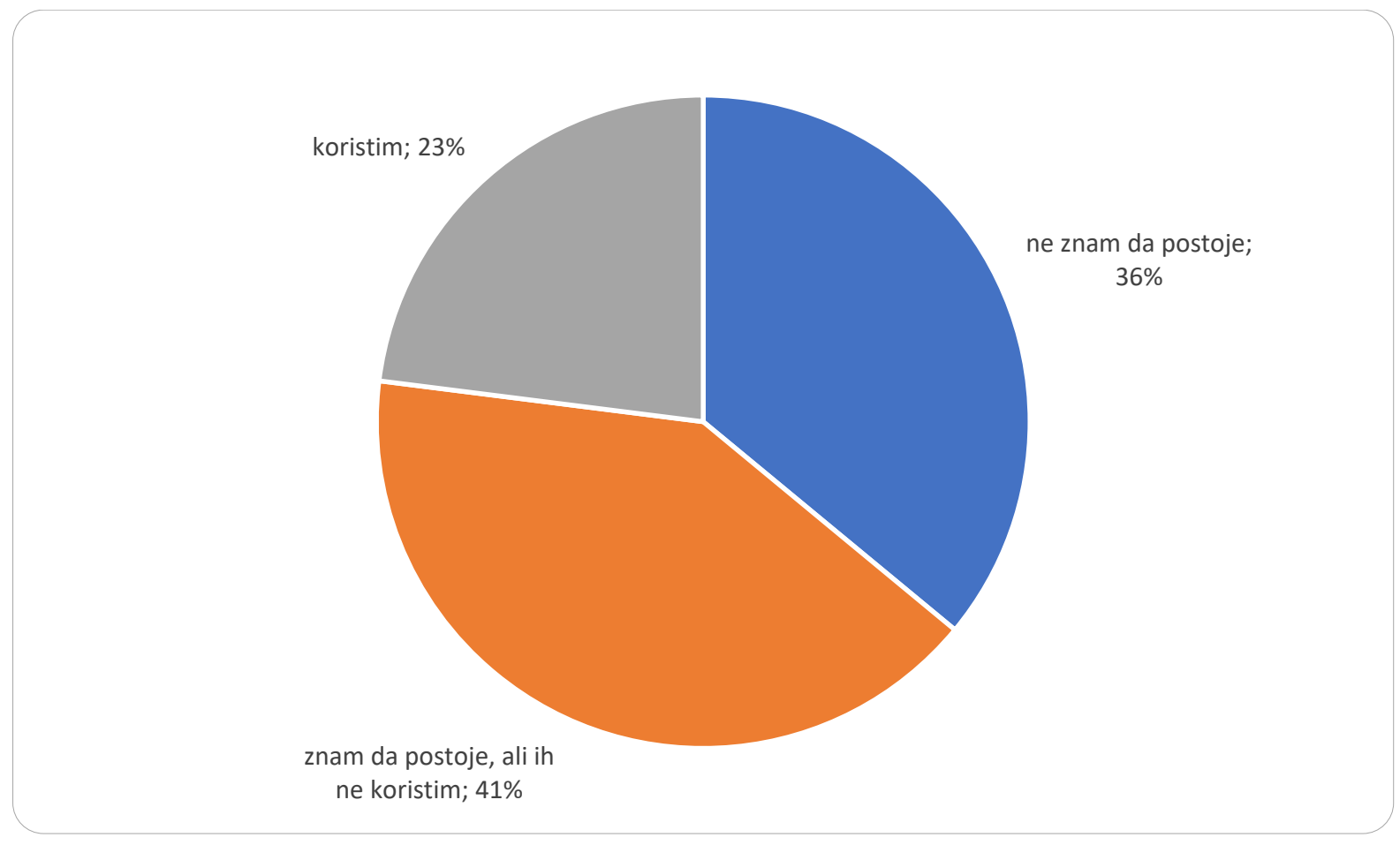

Slika 3: Korišćenje Bulovih operatora u COBISS/OPAC ( $n=100$, u \%)

Poslednji segment ankete odnosio se na primedbe u vezi s pretraživanjem i na subjektivni utisak korisnika o prilagođenosti pretraživanja njihovim mogućnostima i potrebama. Apsolutna većina korisnika (92\%) zadovoljna je rezultatima pretraživanja u COBISS/OPAC, 8\% je delimično zadovoljno, a nezadovoljnih nema. Analiza odgovora anketiranih korisnika, koji 
su delimično zadovoljni pretragom, dala je sledeće rezultate: 2 koristi uputstva, 2 koristi Bulove operatore, 3 koristi skraćivanje zvezdicom.

U pretposlednjem pitanju, ispitanici su se izjašnjavali o eventualnim nedostacima pretraživanja u COBISS/OPAC. Na osnovu dosadašnjeg iskustva u radu s korisnicima, primedbe su formulisali ispitivači, a na raspolaganju je bilo više odgovora (slika 4).

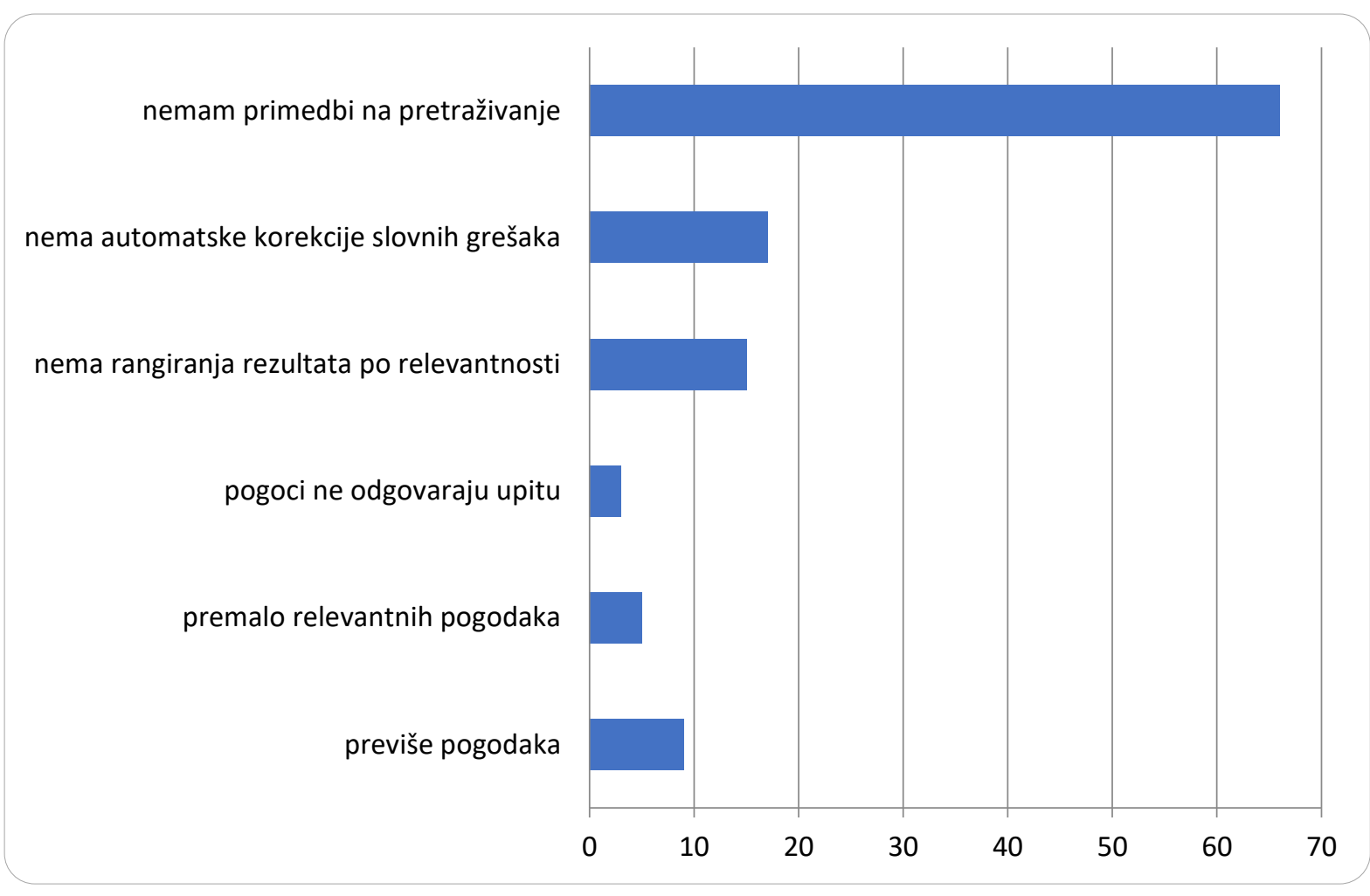

Slika 4: Primedbe na pretraživanje COBISS baze u COBISS/OPAC $(n=100)$

Nepostojanje automatske korekcije slovnih grešaka najčešća je primedba, jer su korisnici navikli da ta opcija postoji na internet pretraživačima. Sledeća primedba odnosi se na rangiranje rezultata po relevantnosti. U COBISS/OPAC postojala je opcija Sortiranje i podrazumevala je grupisanje rezultata po tri kriterijuma (autor, naslov i godina). Korisnici, međutim, očekuju rangiranje prema relevantnosti (na primer, ne očekuju samo sortiranje autora prema abecedi ili godini izdavanja rastuće i opadajuće, već i prema njihovoj rangiranosti na citatnim listama, što je veoma važno kada je reč o stručnim i naučnim radovima).

Ispitanici, čija je primedba iskazana sa previše pogodaka, uglavnom pri pretraživanju koriste ključnu reč.

Niko od ispitanika koji su, kao primedbu, istakli premalo relevantnih pogodaka i pogoci ne odgovaraju upitu ne koristi Bulove operatore, a samo 2 koristi pretraživanje preko predmetne odrednice, što ukazuje na to da korisnici nisu zainteresovani da istraže sve mogućnosti koje im program nudi. Najčešća primedba, koju je uputilo $8 \%$ ispitanika delimično zadovoljnih pretragom, odnosi se na nedostatak automatske korekcije slovnih grešaka (4), na nedostatak 
rangiranja rezultata po relevantnosti (3), na previše dobijenih pogodaka (3) i na to da pogoci ne odgovaraju upitu (1).

Poslednje pitanje odnosilo se na procenu težine procesa pretraživanja u COBISS/OPAC. Većina ispitanika (69\%) smatra da je pretraživanje jednostavno, 31\% smatra da je primereno ličnim mogućnostima, a niko ne smatra da je COBISS/OPAC komplikovan za pretragu.

\section{Diskusija}

Analizom rezultata ankete dolazimo do zaključka da su odgovori istog ispitanika često u koliziji, što je rezultat nedovoljnog znanja o mogućnostima pretrage, neupuštanja u detaljnije upoznavanje baze, oslanjanja na pomoć bibliotekara, kao i prilagođenosti baze stručnim licima (bibliotekarima). Mogućnosti koje nudi COBISS/OPAC nisu u dovoljno iskorišćene, s jedne strane zbog složenosti kataloga, a s druge strane zbog nezainteresovanosti korisnika za istraživanje.

Bez obzira na to što su se saveti za pretraživanje u COBISS/OPAC verziji nalazili na istom ekranu kao i prozor za pretraživanje, nije ih primetila čak trećina korisnika, što ukazuje na njihovu nezainteresovanost za unapređivanje sopstvenih veština u procesu pretraživanja. $S$ druge strane, nazivi pretraživanja nisu bili dovoljno grafički istaknuti, tako da se nije mogao dobiti precizan odgovor na pitanje koje se pretraživanje najčešće koristi. Istraživači pretpostavljaju da je, kao najpreglednije i uglavnom preporučivano tokom obuke, najčešće korišćeno Izborno pretraživanje.

Rezultati ankete su potvrdili prvu hipotezu da se COBISS/OPAC najčešće koristi za pretraživanje po parametrima koji su poznati korisniku (autor, naslov). To je za prosečnog korisnika efikasan način pretraživanja jer ne zahteva previše udubljivanja u tehnike pretraživanja, niti iziskuje mnogo vremena.

Što se tiče olakšica pri pretraživanju, u praksi se pokazalo da se od Bulovih operatora koristi samo AND koji je podrazumevan i primenjuje se automatski, bez intervencije korisnika, a to praktično znači da se Bulovi operatori ne koriste. $U$ radu s korisnicima primećeno je da se zvezdica takođe najčešće pogrešno koristi jer se, umesto na osnovu ili koren, stavlja na kraj reči, čime se gubi njen smisao, ako je upotrebljena u polju za predmetnu odrednicu ili ključnu reč.

Ovim je potvrđena početna hipoteza da korisnici ne koriste ni najjednostavnije olakšice za pretraživanje (Bulovi operatori, skraćivanje).

Odgovori na grupu pitanja, koja se odnose na pretraživanje teme ili oblasti (bez unapred poznatog autora ili naslova), pokazali su da se ključna reč koristi skoro dvostruko više od predmetne odrednice. Ključna reč je jedna od ponuđenih pristupnih tačaka na početnoj maski u izbornom pretraživanju, a predmetna odrednica se bira iz padajućeg menija. Sam koncept ključne reči bliži je korisniku od pojma predmetne odrednice. Preko ključnih reči može se pretražiti sadržaj skoro svih polja u bibliografskom zapisu (naslov, napomene, sažetak - koji se vrlo retko unosi, predmetne odrednice, slobodno oblikovane predmetne odrednice), čime se dobija veliki broj pogodaka, među kojima je malo relevantnih (veliki odziv, ali mala preciznost) (Ristović i Bacotić, 2018, str. 76). 
Kao pristupna tačka, predmetna odrednica se koristi najčešće u situaciji kada se pretražuje nepoznata jedinica građe, a pri tom je jedini poznati parametar tema. Sam pojam predmetne odrednice suviše je apstraktan za korisnike. "Način na koji katalogizator formuliše temu podrazumeva upotrebu određenih alata (tezaurusi, normativne baze, referensna literatura, katalog nacionalne biblioteke i dr.), ali se ipak dešava da usvojeni termin nije u skladu sa načinom razmišljanja prosečnog korisnika." (Ristović i Bacotić, 2018, str. 68). Korisnik formuliše upit prirodnim jezikom, dok je predmetna odrednica formulisana kontrolisanim jezikom. Slobodno oblikovana predmetna odrednica najbliža je načinu razmišljanja korisnika, mada se retko koristi u COBISS.SR. (Prema istraživanju, koje je urađeno 2018. godine, od ukupnog broja zapisa u COBIB.SR (3.223.643), 114.486 zapisa ima popunjeno polje 610 za slobodno oblikovanu predmetnu odrednicu (3,5 \%)) (Ristović i Bacotić, 2018, str. 73).

Rezultati ovog segmenta istraživanja potvrdili su hipotezu da je pretraživanje po predmetu suviše složeno za prosečnog korisnika.

Rezultati ankete potvrdili su tri hipoteze:

1. COBISS/OPAC se najčešće koristi za pretraživanje po parametrima poznatim korisniku (autor, naslov i sl.);

2. korisnici ne koriste sve mogućnosti pretraživanja (Bulovi operatori, skraćivanje);

3. pretraživanje po temi suviše je složeno za korisnika.

Nije potvrđena poslednja hipoteza:

4. korisnici nisu zadovoljni rezultatima pretrage COBISS/OPAC.

Razlog zbog kojeg većina ispitanika smatra da je pretraživanje lako i pri tom su zadovoljni rezultatima pretraživanja, leži upravo u činjenici da se najčešće pretražuju unapred poznati izvori. Za ovakav način pretraživanja dovoljno je samo izbeći greške u pisanju, tako da je razumljivo što je najčešća primedba na pretraživanje nedostatak automatske korekcije slovnih grešaka. Korisnici nemaju strpljenja ni vremena za upoznavanje sa svim opcijama koje nude bibliotečki pretraživači, tako da od raspoloživih opcija za pretraživanje korist imaju samo bibliotekari, za koje se ispostavilo da i pored napredne tehnologije predstavljaju neizostavnu kariku u pronalaženju relevantnih informacija.

\section{Završno razmatranje}

Unapređivanje bibliotečkih kataloga predstavlja temu koja je često zastupljena u stručnoj literaturi. Smatra se da većina onlajn bibliotečkih kataloga ne koristi sve mogućnosti Web okruženja koje bi katalozi treće generacije trebalo da ponude korisnicima (Golub, 2003, str. 3). Prema istraživanjima, idealan pretraživač trebalo bi da ima sledeće karakteristike: jednostavnu navigaciju sa grafički jasno istaknutim smernicama; proveru upita formulacijom Jeste li mislili..., postojanje ključne reči i predmetne odrednice na početnoj strani za pretraživanje; isticanje pojmova, koje je korisnik uneo u pretraživač, pri ispisu rezultata; nizanje rezultata prema relevantnosti; predlaganje sličnih naslova prema predmetu, sadržaju i čitanosti; korisničko označavanje (evaluacija publikacije od drugih korisnika); ispis bibliografskih jedinica obogaćenih grafičkim, tekstualnim sadržajem (slikom omota, sažetkom ili sadržajem iz publikacije); jednostavan pristup drugim bazama podataka sa kojima je biblioteka povezana itd. (Wynne and Hanscom, 2011, str. 180). 
Korisnik očekuje da dođe do informacije brzo i jednostavno, sa što manje klikova, a to govori u prilog tome da bibliotečki katalozi ne mogu biti izolovani, već treba da budu povezani sa što više relevantnih baza podataka. U odnosu na druge izvore podataka na internetu, prednost biblioteke leži u činjenici da ona predstavlja portal koji vodi do proverene i pouzdane informacije i koji se mora nametnuti kao nezaobilazni put u potrazi za znanjem.

\section{Reference}

Davidovski, B. i Marinčić, B., 2019. Primena novih tehnologija u radu sa decom i mladima u Narodnoj biblioteci Užice. U: Čeliković, K. ur. Dani hrvatske knjige i riječi: zbornik radova 2018. Subotica: Hrvatska čitaonica i Zavod za kulturu vojvođanskih Hrvata. Str. 133-150.

Golub, K., 2003. Predmetno pretraživanje u knjižničnim katalozima s web-sučeljem. Magistarski rad. Zagreb: Sveučilište u Zagrebu, Filozofski fakultet.

Svenonius, E., 2007. Intelektualna osnova organizovanja informacija. Beograd: Narodna biblioteka Srbije i Clio.

Wynne, S. C. i Hanscom, M. J., 2011. The effect of next-generation catalogs on catalogers and cataloging functions in academic libraries. Catologing \& Classification Quarterly, 49(3), str. 179-207.

Ristović, B. i Bacotić, G., 2018. Slobodno oblikovana predmetna odrednica i potrebe korisnika. Bibliotekar, 60(1), str. 67-79.

Ršumović, I. ur., 2006. Narodna biblioteka Užice: 1856-2006: 150 godina postojanja. Užice: Narodna biblioteka.

Šokica, N., 2005. Pretraživanje uzajamnog kataloga - COBISS/OPAC. Infoteka, 6, str. 33-41. 